\title{
WIELOPŁASZCZYZNOWY CHARAKTER LEKCJI JĘZYKA OBCEGO
}

\author{
A MULTIDIMENSIONAL CHARACTER \\ OF A FOREIGN LANGUAGE LESSON
}

TERESA SIEK-PISKOZUB, ALEKSANDRA WACH

\begin{abstract}
A foreign language lesson is an interesting and complex event, with a specific structure, social roles ascribed to the participants, and a set of relevant objectives which it aims to fulfill as part of a certain teaching methodology. Following the various perspectives on a lesson which were identified by Prabhu ${ }^{1}$, the article aims to emphasize the multidimensional nature of a foreign language lesson. Therefore, a lesson is scrutinized as a basic unit of a syllabus, as a way of operationalizing a teaching method, as a social event, as a scene of social interaction, and as an experience fostering the development of teachers' competence.
\end{abstract}

Teresa Siek-Piskozub, Aleksandra Wach, Uniwersytet im. Adama Mickiewicza w Poznaniu, Poznań - Polska.

\section{Wstęp}

W ostatnim czasie zamarła w Polsce dyskusja nad znaczeniem lekcji języka obcego jako czynnika współodpowiedzialnego za osiągnięcia dydaktyczne. Zainteresowania glottodydaktyków skierowane są na problemy natury ogólnej, jak np. stosowanie strategii uczenia się (np. Droździał-Szelest²) lub nauczania języków obcych (Siek-Piskozub3; Siek-Piskozub, Wach ${ }^{4}$ ), autonomia ucznia (Wilczyńska5; Pawlak6), nauczanie uczniów specyficznych,

1 N.S. P r a b h u, The dynamics of the language lesson, "TESOL Quarterly" 1992, no. 26(2), s. 225-241.

${ }^{2} \mathrm{~K}$. D r o ź d z i a 1 - S z e l e s t, Language learning strategies in the process of acquiring a foreign language, Poznań 1997.

${ }^{3}$ T. S i e k - P i s k o z u b, Uczyć się bawiąc. Strategia ludyczna na lekcji języka obcego,Warszawa 2001.

4 T. S i e k - P i s k o z u b, A. W a c h, Muzyka i stowa. Rola piosenki w procesie przyswajania języka obcego, Poznań 2006.

${ }^{5} \mathrm{~W}$. W i 1 c z y ń s k a, Uczyć się czy być nauczanym. O autonomii w nauczaniu języka obcego, Warszawa-Poznań 1999. 
np. dzieci (Szpotowicz, Szulc-Kurpaska7; Sikora-Banasik ${ }^{8}$ ), uczniów z problemami (Zawadzka-Bartnik ${ }^{9}$ ), czy nauczanie dwujęzyczne (Iluk10; Zielonka11). Glottodydaktycy zwracają też uwagę na problemy szczegółowe związane z kompetencją językową, takie jak miejsce gramatyki we współczesnym podejściu do nauczania języka (Pawlak12), nauczanie sprawności (Zawodniak $\left.{ }^{13}\right)$, czy potrzeba i sposób rozwijania interkulturowej kompetencji komunikacyjnej (Komorowska14). Liczba publikacji, zarówno polskich, jak i zagranicznych, na temat lekcji języka obcego jako jednostki dydaktycznej jest natomiast niewielka, choć zdarzają się pozycje dotyczące poszczególnych aspektów prowadzenia lekcji w nauczaniu różnorodnych grup uczniów (np. Komorowska15).

Problem lekcji języka obcego z perspektywy nauczania frontalnego omawiał w 1979 roku Sylwestrowicz ${ }^{16}$, który przeanalizował różne możliwe typy lekcji i warunki, w jakich mogą one przebiegać, oraz kryteria ewaluacji lekcji. Woźniewicz ${ }^{17}$ podjął problem lekcji w podejściu zorientowanym na komunikację, kontrastując podejście komunikacyjne z tradycyjnym podejściem nauczeniowym, reprezentowanym - zdaniem autora - przez nauczanie zgodne zarówno z metodą audiolingwalną, jak i kognitywną. Autor, inaczej niż Sylwestrowicz, konstruuje typologie lekcji, biorąc pod uwagę kryterium sprawności, a także oddzielnie omawia lekcję integrującą sprawności. Czy w związku z tym, że podejście komunikacyjne, choć zmo-

${ }^{6}$ Autonomia w nauce języka obcego, M. Pawlak (red.), Kalisz-Poznań 2004.

${ }^{7}$ M. S z p o t o w i c z, M. S z u l c - K u r p a s k a, Teaching English to young learners, Warszawa 2010

8 Wczesnoszkolne nauczanie języków obcych. Zarys teorii i praktyki, D. Sikora-Banasik (red.), Warszawa 2010.

${ }^{9} \mathrm{E}$. Z a w a d z k a - B a r t n i k, Nauczyciel języków obcych i jego niepetnosprawni uczniowie (z zaburzeniami i dysfunkcjami), Kraków 2010.

10 J. I 1 u k, Problemy ksztatcenia dwujęzycznego w Polsce, "Języki Obce w Szkole” 2002, nr 6, s. 27-36.

${ }_{11}$ B. Z i e 1 o n k a, Poland, [w:] Windows on CLIL: Content and Language Integrated Learning in the European spotlight, A. Maljers/ D. Marsh/ D. Wof (red.), Graz 2007, s. 147-154.

$12 \mathrm{M}$. P a w $1 \mathrm{a}$ k, The place of form-focused instruction in the foreign classroom, KaliszPoznań 2006.

${ }^{13} \mathrm{~J} . \mathrm{Z}$ a w o d n i a k, Rozwijanie sprawności pisania w dydaktyce językowej na etapie wczesnoszkolnym, Zielona Góra 2009.

${ }^{14} \mathrm{H}$. K o m o r o w s k a, Język i kultura w dydaktyce języków obcych, "Kwartalnik Pedagogiczny" 2006, nr 4, s. 28-44.

15 Skuteczna nauka języka obcego. Struktura i przebieg zajęć językowych, H. Komorowska (red.), Warszawa 2009.

16 J. S y 1 w e s t r o w i c z, Lekcja jezzyka obcego, Warszawa 1979.

17 W. W o ź n i e w i c z, Metodyka lekcji języka rosyjskiego, wyd. II, Warszawa 1991. 
dyfikowane, nadal obowiązuje, jest to już problem zamknięty, dobrze rozpoznany przez badaczy i praktyków? Mamy co do tego wątpliwości.

Prabhu ${ }^{18}$ zwraca uwagę na niezwykle złożony charakter lekcji, a zwłaszcza lekcji języka obcego, i możliwe konflikty między potrzebami uwzględnienia różnych funkcji, jakie lekcja powinna pełnić.

W artykule chcemy skupić się na lekcji jako pewnym wydarzeniu zachodzącym w klasie, które może, choć nie musi, sprzyjać rozwojowi ucznia jako osoby, w tym też jego kompetencji komunikacyjnej w języku obcym. Patrząc z perspektywy nauczyciela, lekcja jako wydarzenie zachodzące w szkole, a wiec ważnej instytucji społecznej, powinna podlegać procesowi nieustannego doskonalenia, ale zależy to tylko od kompetencji nauczyciela i jego wysiłków. Nauczyciel musi mieć bowiem świadomość wielopłaszczyznowego charakteru lekcji i możliwych wewnętrznych konfliktów. Musi też świadomie poszukiwać najlepszych rozwiązań, budować i weryfikować własne teorie uczenia się i nauczania w oparciu o swoją wiedzę i bezpośrednie doświadczenie. Nauczyciel-badacz jest lepiej zmotywowany do samorozwoju i łatwiej uniknie procesu wypalenia zawodowego. W naszej analizie posłużymy się wyodrębnionymi przez Prabhu ${ }^{19}$ perspektywami, poszerzając je wszakże o własne przemyślenia, obserwacje oraz lektury, a także refleksje wynikające $\mathrm{z}$ obserwacji kilkudziesięciu lekcji przeprowadzonych przez nauczycieli-praktykantów, studentów filologii angielskiej, $\mathrm{w}$ ramach ich praktyk szkolno-pedagogicznych realizowanych w szkołach podstawowych i gimnazjum.

\section{Lekcja jako jednostka programu}

Najbardziej oczywistą, jakby się zdawało, cechą lekcji jest fakt, że stanowi ona jednostkę dydaktyczną $\mathrm{w}$ ramach pewnego kursu (Prabhu ${ }^{20}$ ). Ta perspektywa wymusza spojrzenie na lekcję jako na systematyczne przechodzenie przez nauczyciela i ucznia przez treści zawarte w przyjętym programie nauczania oraz ich utrwalania. Niezbędne w tym celu jest określenie celów ogólnych wyznaczonych przez program, jak i celów węższych, szczegółowych, realizowanych w ramach każdej lekcji lub sekwencji lekcji. Cele te powinny przybliżać do osiągnięcia celu końcowego. Cele lekcji występują więc w relacji do celów lekcji poprzedzających, jak i następujących. Należy też pamiętać, że współczesna dydaktyka kładzie nacisk nie tylko na cele poznawcze (co nowego uczeń pozna), ale też kształcące (co będzie umiał sam zrobić) oraz wychowawcze (motywacje i postawy). Takie cele przedstawione są w podstawie programowej kształcenia ogólnego opracowanej przez

\footnotetext{
18 N.S. P r a b h u, The dynamics..., op. cit. s. 225

19 Ibidem.

${ }^{20}$ Ibidem, s. 226.
} 
Ministerstwo Edukacji Narodowej21. Dotyczy to funkcjonowania w szkole jako takiej, w trakcie całego procesu dydaktycznego, jak i w odniesieniu do każdego przedmiotu nauczania i każdej lekcji.

$\mathrm{Z}$ takim ujęciem wiąże się założenie postępu wiedzy, umiejętności oraz rozwój pożądanych postaw u ucznia, a więc przekonanie, że lekcja ma bezpośredni wpływ na rozwój ucznia w pożądanym kierunku. Wpływ ten powinien być monitorowany, stąd zalecenia pedagogów, aby pod koniec lekcji określić, czy jej cel został osiągnięty.

Nie ma jednej powszechnie stosowanej koncepcji strukturyzowania lekcji. Farrell22 proponuje zaadaptowaną od Shrum i Glisan ${ }^{23}$ pięciofazową strukturę: (1) „perspektywa/otwarcie”, w czasie którego nauczyciel uświadamia uczniom, co wcześniej robili lub opanowali; (2) „stymulacja” - poprzez pytania nauczyciel kieruje uwagę uczniów na planowane działanie, jego związek z ich życiem rzeczywistym, stosując techniki ludyczne (anegdotę, piosenkę, dramę), motywuje ich do udziału w działaniu; (3) "nauczanie/udział" jest dominantą lekcji ukierunkowaną na wyznaczone cele; (4) „zamknięcie” - nauczyciel wraz z uczniami ustala, czego się nauczyli oraz co będzie ćwiczone na kolejnych lekcjach; (5) „uzupełnienie” - rozszerzenie wprowadzonego materiału o nowe ćwiczenia i interakcje. Podobnie, Woźniewicz ${ }^{24}$ wyodrębnia następujące cztery fazy lekcji, z których każda spełnia określone, istotne funkcje: (1) początek lekcji, (2) realizacja głównego celu lekcji, (3) czynności utrwalające i korekcyjno-kontrolne oraz (4) zakończenie lekcji. Niektórzy nauczyciele (np. Siek-Piskozub25, Żyła ${ }^{26}$ ) uważają za pożądane wprowadzenie na początku każdej lekcji rozgrzewki językowej, która pozwoli uczniom przestawić się z języka ojczystego na obcy, a także ze spraw, które absorbowały ich na poprzednich lekcjach i przerwie, na nowe zadania. Treści, na których skoncentrować można rozgrzewkę, to bieżące wydarzenia w szkole czy aktualne doświadczenia poszczególnych uczniów lub wybrana technika ludyczna. Rozgrzewka tym może różnić się od proponowanego przez Farrella ${ }^{27}$ ogniwa trzeciego, że

\footnotetext{
${ }^{21}$ http://www.men.gov.pl/index.php?option=com_content\&view=article\&id=2032 \&Itemid=106

22 T. F a r r e 1 1, Lesson planning, [w:] Methodology in language teaching. An anthology of current practice, J.C. Richards i W.A. Renandya (red.), Cambridge 2002, rozdz. 3, s. 30-39.

${ }^{23}$ J.L. S h r u m, E. G 1 i s a n, Teacher's handbook: Contextualized language instruction, Boston 1994.

${ }^{24}$ W. W o ź n i e w i c z, Metodyka lekcji..., op. cit., s.100-101.

25 T. S i e k - P i s k o z u b, Rozgrzewka językowa, "Języki Obce w Szkole" 1990, nr 5, s. 337-341.

${ }^{26}$ L. Ż y ł a, Rozgrzewka językowa, czyli pierwsze pięć minut lekcji języka obcego, "Języki Obce w Szkole" 1990, nr 5, s. 335-337.

27 T. F a r r e 11, Lesson..., op. cit.
} 
niekoniecznie musi bezpośrednio wiązać się z głównymi poznawczymi celami, choć biorąc pod uwagę, że jest prowadzona w języku obcym, ma wpływ na rozwój sprawności lub tych aspektów systemu językowego, które są $\mathrm{w}$ niej wykorzystywane (są to więc cele funkcjonalne); może też pełnić funkcje wychowawcze.

Czy nauczyciel jest w stanie dokładnie określić poziom każdego ucznia w zakresie poznawczym, funkcjonalnym i wychowawczym, aby dla każdej lekcji określić cele dla niego osiągalne (ogniwo 1)? Czy na lekcji języka obcego nauczyciel jest w stanie określić, czego uczniowie właśnie się nauczyli (ogniwo 4)? Z pewnością nie.

Obserwowane lekcje przeprowadzone przez nauczycieli-praktykantów pokazały, jak trudnym zadaniem jest realizacja celów lekcji poprzez nadanie jej spójnej, logicznej struktury. Najczęstsze problemy dotyczyły położenia nieproporcjonalnie dużego nacisku na te fazy lekcji, które prowadzą do osiągnięcia celów poznawczych, przy niedostatecznym uwzględnieniu lub wręcz pominięciu celów kształcących oraz wychowawczych. Praktykanci koncentrowali się na wprowadzaniu nowego materiału, często w sposób mechaniczny, nie zawsze dostosowany do możliwości poznawczych uczniów, ograniczając czas przeznaczony na ćwiczenie poznanego materiału w sytuacjach komunikacyjnych (a więc na ćwiczenie sprawności).

Programy nauczania, jakkolwiek pomocne, a nawet niezbędne w kształceniu masowym jako punkt odniesienia, są jedynie pewnym drogowskazem, wytyczają kierunki, wszakże tylko w ramach przyjętych założeń, pewnych uogólnień dotyczących rozwoju jednostki w ramach wyznaczonych kompetencji. Nasza wiedza na temat uczniów jest z powodów oczywistych ograniczona, często oparta na fałszywych przesłankach, jednostkowych obserwacjach, np. czy uczeń udzielił właściwej odpowiedzi na pytanie, czy zgłasza się do odpowiedzi. „Właściwa odpowiedź” nie musi oznaczać rozumienia, a brak widocznej aktywności nie musi być dowodem na nieuczestniczenie $\mathrm{w}$ procesie uczenia się, na co wskazały badania Saville-Troike ${ }^{28}$ nad tzw. mową prywatną (ang. private speech).

Podobnie jest $\mathrm{z}$ wiedzą przedmiotową. Dyskusja nad tym, czym jest kompetencja językowa w kontekście języka nieojczystego, trwa i zapewne nigdy się nie zakończy, bo też zmianie podlega sytuacja, w jakiej języki obce są niezbędne, możliwości kontaktów pozaszkolnych $w$ języku docelowym, znaczenie - a w związku z tym niezbędny zakres znajomości - poszczególnych języków w świecie realnym, itd. Pokazuje to, że nauczyciel w sposób świadomy decydować musi o celach lekcji i jej przebiegu, nie tylko $\mathrm{z}$ punktu widzenia założonego programu, ale też z punktu widzenia swo-

${ }_{28}$ M. S a v i 11 e - T r o i k e, Private speech: evidence for the second language strategies during the silent period, "Journal of Child Language" 1988, no. 15, s. 567-590. 
ich uczniów, ich potrzeb i możliwości. Pojedynczy uczniowie, a nawet całe grupy, mogą nie być w stanie realizować założonego programu. Program realizowany musi różnić się od założonego, co więcej, program osiągnięty przez poszczególnych uczniów też będzie zróżnicowany. Odstępstwa od założeń programowych przełożą się na konieczne modyfikacje w planowaniu i realnym przebiegu lekcji. Nie tylko z obserwacji praktykantów widać, że nauczyciele języków obcych na ogół koncentrują się na celach poznawczych (wiedza o kulturze) i funkcjonalnych (sprawności językowe), zapominając o celach wychowawczych lekcji w szerszym wymiarze niż utrzymanie dyscypliny $\mathrm{w}$ klasie. Jest to wyraźne, gdy analizuje się programy zawarte $w$ podręcznikach do nauczania.

Zaniedbywanie celów wychowawczych lekcji było częstym zjawiskiem na obserwowanych lekcjach prowadzonych przez praktykantów. Choć $\mathrm{z}$ jednej strony jest to zrozumiałe u niedoświadczonych nauczycieli, którzy przecież nie pracowali z daną klasą na co dzień, z drugiej strony zachowania takie, jak na przykład nieznajomość i brak chęci poznania imion uczniów czy ignorowanie pewnych ewidentnych konfliktów interpersonalnych pomiędzy uczniami, prowadzi do refleksji, że uświadomienie praktykantom wagi funkcji wychowawczej w procesie nauczania jest sprawą konieczną.

Jednakże nawet doświadczeni nauczyciele mają problemy wychowawcze i nie postępują zgodnie z zaleceniami pedagogów. Badanie Góreckiej $(2007)^{29}$ pokazuje, że nie zawsze uświadamiają sobie wpływ własnych opinii i zachowań na postępowanie uczniów. Z ankietowanej, a następnie obserwowanej czwórki nauczycieli o stażu od 5 lat do 28 lat wszyscy potwierdzili, że najczęściej ignorują niepoprawne zachowania, bo ich uczniowie i tak się wkrótce tym znudzą; troje zdecydowanie zgadzało się z opinią (5 pkt. w skali Likerta), że tylko studenci są odpowiedzialni za brak dyscypliny, podczas gdy czwarty nauczyciel zgodził się z tą opinią; trójka zdecydowanie potwierdziła, że zadają przeszkadzającemu uczniowi pytania, na które ten nie zna odpowiedzi, oraz że za dobry sposób przywrócenia dyscypliny uważają pokrzykiwanie na uczniów. Obserwacje zachowań na lekcji potwierdziły stosowanie wspomnianych strategii.

\section{Lekcja jako operacjonalizacja metody}

Innym możliwym spojrzeniem na lekcję jest potraktowanie jej jako sposobu wprowadzenia pewnej metody nauczania, a więc jest to operacjonalizacja metody w sposób systematyczny (Prabhu ${ }^{30}$ ). Lekcja staje się sekwencją zadań wyznaczonych przez nauczyciela uczniom. Nauczyciel, obok celów

${ }^{29}$ A. G ó r e c k a, Non-verbal and verbal techniques of dealing with discipline problems in EFL classroom. Niepublikowana praca magisterska, Torun 2007.

${ }^{30}$ N.S. P r a b h u, The dynamics..., op. cit., s. 227. 
przypisanych każdej lekcji, przewiduje kolejność zadań, potrzebny na ich wykonanie czas oraz monitoruje ich przebieg. Lekcja jest więc wydarzeniem dydaktycznym.

Podczas gdy perspektywa lekcji jako jednostki programu wymusza potrzebę świadomości, jakie są relacje pomiędzy poszczególnymi jednostka$\mathrm{mi}$, to perspektywa operacjonalizacji przyjętej metody oparta jest na przyjęciu pewnej teorii uczenia się, a zastosowane techniki/działania powinny z nią współgrać. Zakładamy też, że jest to teoria prawdziwa. Nie ma wszakże jednej powszechnie uznanej teorii nauczania. Stąd u glottodydaktyków zorientowanych na praktykę często wysuwany jest postulat integrowania, eklektyzmu (np. Pfeiffer ${ }^{31}$ ), choć są też tacy, którzy są temu raczej przeciwni (np. Marton ${ }^{32}$ ). Współczesne podręczniki, a raczej całe zestawy dydaktyczne, wyposażone są $\mathrm{w}$ książkę nauczyciela $\mathrm{z}$ zawartymi $\mathrm{w}$ niej sugestiami w formie planów lekcji i komentarzy. Nauczyciele wykorzystują kurs, często jednakże nie mają świadomości założeń teoretycznych odnośnie kompetencji językowej oraz teorii uczenia się, na której zestaw jest oparty, bądź wręcz nie zgadzają się z tymi założeniami. Modyfikują wtedy polecenia; zadanie czytania ze zrozumieniem może zamienić się $\mathrm{w}$ zadanie głośnego odczytania kolejnych zdań i ich przetłumaczenia, ćwiczenie na słuchanie ze zrozumieniem może zmienić się na zdanie przeczytania tekstu zamieszczonego w części, gdzie są klucze, itp. To obserwacja takich zachowań jest zapewne powodem niechęci teoretyków do eklektyzmu.

Znajduje to potwierdzenie $\mathrm{w}$ obserwowanych lekcjach przeprowadzonych przez nauczycieli-praktykantów. Stosowane przez nich techniki nauczania często nie były spójne z założeniami teoretycznymi kursów, w ramach których nauczali. Czytanie na głos i tłumaczenie tekstów i dialogów, a także tłumaczenie na język ojczysty wprowadzanego słownictwa było stosowane przez około jedną trzecią praktykantów. Zapytani po lekcji, czemu miały służyć te techniki, nie potrafili udzielić odpowiedzi, co pokazuje, że automatycznie powielali wzorce znane z własnych doświadczeń uczenia się języka, nie starając się zintegrować nabytej wiedzy w zakresie teorii przyswajania i nauczania języka obcego z praktyką.

Podejście komunikacyjne do nauczania języka obcego kładzie nacisk na znaczenie, personalizację treści nauczania oraz ćwiczenie płynności wypowiedzi. W obserwowanych lekcjach natomiast zbyt dużo było ćwiczeń bardzo kontrolowanych, mechanicznych, przypominających dryl językowy. Często brakowało czasu na ćwiczenia komunikacyjne, których celem byłby rozwój płynności wypowiedzi, a nie tylko jej poprawności językowej. Personalizacja treści również była zaniedbanym aspektem zadań językowych.

31 W. P f e i f f e r, Nauczanie języków obcych. Od praktyki do praktyki, Poznań 2001.

32 W. M a r t o n, Methods in English language learning, Cambridge 1988. 
Takie rozwiązania dydaktyczne nie tylko sygnalizują brak spójności pomiędzy metodą nauczania a jednostką lekcyjną, ale również przyczyniają się do monotonii w sposobie prowadzenia lekcji.

\section{Lekcja jako wydarzenie społeczne}

Kolejna proponowana przez Prabhu ${ }^{33}$ perspektywa to spojrzenie na lekcje jako wydarzenie społeczne. Jest to wydarzenie w znacznym stopniu zrutynizowane, z wyznaczonymi rolami zarówno dla uczniów, jak i nauczycieli, gdyż, jak podkreśla Woźniewicz ${ }^{34}$, zarówno nauczyciel, jak i uczniowie są członkami pewnej grupy społecznej, jaką jest klasa językowa. Woźniewicz ${ }^{35}$ wyróżnia dwie podstawowe role pełnione przez nauczyciela w trakcie lekcji języka obcego: rolę „nauczeniową", polegającą między innymi na organizowaniu, kontrolowaniu i ocenianiu pracy klasy, oraz rolę „partycypacyjną", wyrażającą się w aktywnym uczestnictwie nauczyciela w zadaniach komunikacyjnych.

Lekcja ma pewną strukturę, której na ogół nie zauważamy, gdy wszystko idzie zgodnie z planem, a której świadomość wzrasta, gdy zostaje zakłócona. Zakłócenie przybierać może różne formy zależne od wyznaczonych uczniom ról. W klasie nauczyciela autorytarnego, który w dalszym ciągu nie jest rzadkością $\mathrm{w}$ warunkach polskich (Łastowska ${ }^{36}$ ), takim zakłóceniem może być nadmierna ciekawość niektórych uczniów przeszkadzających nauczycielowi pytaniami, które nie współgrają z celami lekcji, bądź komentowanie wypowiedzi innych uczniów, co nauczyciel uważa za swoją domenę. Nauczyciel przekonany o wartości interakcji między uczniami w języku obcym za zakłócenia uznać może pasywną postawę uczniów niechętnych do przejmowania odpowiedzialności za proces uczenia się, z czym nierzadko mamy do czynienia przy wprowadzaniu takich technik jak projekt zespołowy czy symulacja. Ról społecznych należy więc uczyć, wskazywać na możliwości i ograniczenia poszczególnych podejść. W tym właśnie zawarte są cele wychowawcze, tak często pomijane przy planowaniu lekcji i rzadko werbalizowane przy sporządzaniu takiego planu.

Lekcja widziana z perspektywy społecznej powinna być też analizowana pod kątem bezpieczeństwa oferowanego uczestnikom, tj. nauczycielowi i uczniom - i to zarówno jako jednostkom, jak i całości. Jej prawidłowy przebieg możliwy jest, gdy wszyscy mają poczucie bezpieczeństwa, gdy brak jest zachowań nieprzewidywalnych lub społecznie nieakceptowal-

${ }^{33}$ N.S. P r a b h u, The dynamics..., op. cit., s. 227.

${ }^{34}$ W. W o ź n i e w i c z, Kierowanie procesem glottodydaktycznym, Warszawa 1987, s. 263.

35 Ibidem, s. 265

36 A. Ł a s t o w s k a, Group work from EFL teachers' and learners' perspective. Niepublikowana praca magisterska, Poznań 2011. 
nych, takich jak np. wzajemne obrażanie siebie czy to przez uczniów, czy to przez nauczyciela. Im częściej pewne zachowania występują w klasie, tym większa jest potrzeba ich zrutynizowania, oparcia na wyznaczonych i/lub przyjętych zasadach. Ponadto zasada społecznego współuczestnictwa w procesie dydaktycznym dotyczy nie tylko nauczyciela i jego uczniów, ale całej społeczności szkolnej, tj. wszystkich nauczycieli, którzy powinni wspólnie ustalić zasady akceptowalnych zachowań, jak również rodziców. Uczniowi wywodzącemu się z rodziny autorytarnej trudno jest przejąć na siebie część odpowiedzialności za proces uczenia się, bo oczekuje tego od swoich wychowawców. Może on mieć też tendencję do przejmowania autorytarnych postaw obserwowanych $\mathrm{w}$ domu wobec swych kolegów, których z różnych powodów może uważać za słabszych. Odwrotnie, uczniowi wychowywanemu $\mathrm{w}$ rodzinie o zasadach partnerskich trudno jest zaakceptować autorytarny styl nauczania, przyjmować całkowicie podporządkowaną nauczycielowi rolę, powstrzymać się od wyrażania własnych opinii.

Nie jest więc łatwo wprowadzić zasadę rutyny, która gwarantuje poczucie bezpieczeństwa, zwłaszcza że nadmierna rutyna prowadzi też to odbioru lekcji jako nudnej. Zasada wprowadzenia zachowań zrutynizowanych w klasie jest wszakże niezbędna ze względu na powtarzalność lekcji jako wydarzenia społecznego.

Zrutynizowane zachowania nauczyciela i uczniów w klasie językowej wyrażają się między innymi w użyciu zwrotów językowych, tak zwanego języka zarządzania klasą (ang. classroom management language), w celu ustalenia konkretnych zasad i uzyskania pewnych zachowań. Zrutynizowany język lekcji obejmuje więc, na przykład, powitanie, sprawdzanie obecności, wydawanie poleceń, pożegnanie się z uczniami. Obserwacja lekcji prowadzonych przez praktykantów wskazuje, że ten aspekt prowadzenia lekcji językowej jest zaniedbany; praktykanci często zapominali o formalnym rozpoczęciu i zakończeniu lekcji, wydawali niejasne, dwuznaczne polecenia, koncentrowali się bardziej na zadaniach językowych niż na stworzeniu atmosfery wspólnoty i współpracy. Co więcej, zarządzanie klasą odbywało się często $w$ języku ojczystym, podczas gdy stosowanie języka obcego do wprowadzania zrutynizowanych zachowań ma wysokie walory dydaktyczne. Uczniowie ćwiczą rozumienie ze słuchu, koncentrują się na znaczeniu, uczą się stosowania strategii komunikacyjnych (np. Scrivener ${ }^{37}$ ). Co gorsza, są to też nawyki doświadczonych nauczycieli, którzy w dużym stopniu komunikują się z uczniami w języku ojczystym (zob. np. Majer ${ }^{38}$, Niżegorodcew $\left.{ }^{39}\right)$.

37 J. S c r i v e n e r, Teaching English. The Essential Guide to English Language Teaching, Oxford 2005, s. 100-101.

$38 \mathrm{~J} . \mathrm{M}$ a j e r, Interactive discourse in the FL classrom, Łódź 2003.

${ }^{39} \mathrm{~A} . \mathrm{N}$ i ż e g o r o d c e w, Input for instructed L2 learners, Clevedon 2006. 


\section{Lekcja jako arena interakcji społecznych}

Należy też spojrzeć na lekcję jako arenę interakcji między wszystkimi uczestnikami procesu dydaktycznego (Prabhu $\left.{ }^{40}\right)$. W tym sensie lekcja staje się namiastką życia realnego, przy jednoczesnym zachowaniu minimum bezpieczeństwa wynikającym ze sformalizowania systemu edukacji i wszelkich jego komponentów. Farrell i Jacobs ${ }^{41}$ podkreślają społeczny charakter procesu uczenia się języka obcego, co oznacza, że uczniowie efektywnie uczą się nie tylko od nauczyciela czy z materiałów dydaktycznych, ale przede wszystkim od siebie nawzajem. Stąd istotna rola budowania wspólnoty w klasie językowej, której sprzyja wprowadzanie atmosfery współpracy oraz wzajemnego zaufania.

Ta perspektywa sprzyja również rozwojowi kompetencji komunikacyjnej. Jest to spotkanie różnych indywidualności, pozwalających na poznanie złożoności życia społecznego i wewnętrznego. Uczeń ma okazję skonfrontowania własnego obrazu siebie $\mathrm{z}$ obrazem wytworzonym przez innych - nauczyciela i pozostałych uczniów. Ma okazję poznawać różne osobowości, przyjmować różne postawy i wyrażać swoją opinię, konfrontując się przy tym z innymi i obserwując reakcje innych. Jest to więc niezwykle złożona perspektywa, która pozwala na poznanie różnych osobowości i relacji, zwłaszcza wśród uczniów. Oczywiście jest to możliwe wtedy, gdy lekcje zorientowane są na ucznia, jego całościowy rozwój, interakcję z innymi, a nie tylko na realizację celów związanych z wąsko pojętą kompetencją przedmiotową.

Zachęcanie uczniów do wchodzenia w interakcje pomiędzy sobą okazało się dużym wyzwaniem dla obserwowanych nauczycieli-praktykantów. Stanowczo zbyt rzadko decydowali się na wprowadzanie zróżnicowanych formatów interakcji, takich jak praca $\mathrm{w}$ parach lub małych grupach, $\mathrm{w}$ wyniku czego lekcje były w zbyt dużym stopniu zorientowane na nauczyciela, a uczniowie nie mieli zbyt wielu okazji wypowiadania się $\mathrm{w}$ języku angielskim w czasie lekcji. Taka preferencja dla nauczania frontalnego wśród młodych nauczycieli-praktykantów może budzić zdziwienie, gdyż $\mathrm{w}$ literaturze przedmiotu oraz na zajęciach z dydaktyki języka obcego wyraźnie zaznaczane są korzyści płynące z wprowadzania zadań opartych na interakcji między uczniami (np. Johnson ${ }^{42}$ ).

Kolejny zaobserwowany problem dotyczył niechęci praktykantów do aktywnego monitorowania pracy uczniów w parach lub małych grupach.

40 N.S. P r a b h u, The dynamics..., op. cit., s. 229.

${ }^{41} \mathrm{~T}$. F a r r e 1 1, G. J a c o b s, Essentials for successful English language teaching, London 2010, s. 30-35.

$42 \mathrm{~K} . \mathrm{J}$ o h n s o n, An Introduction to Foreign Language Learning and Teaching. Second edition, Harlow 2008, s. 344. 
Krążenie po klasie, monitorowanie i nadzorowanie pracy uczniów ma istotne znaczenie zarówno dydaktyczne (uczniom łatwiej wtedy poprosić o pomoc, ponadto nauczyciel widzi, jak uczniowie sobie radzą z danym zadaniem), jak i psychologiczne (uczniowie odczuwają obecność i bliskość nauczyciela, przez co czują się bezpieczni i docenieni). Jednak około połowa z obserwowanych praktykantów unikała tego typu zachowań, pozostawiając uczniów samym sobie. Najwyraźniej potrzeba czasu i doświadczenia, aby poczuć się pewnie w społecznej roli pedagoga.

\section{Lekcja jako doświadczenie rozwoju kompetencji nauczyciela}

Prabhu ${ }^{43}$ widzi możliwości konfliktu między poszczególnymi płaszczyznami. Cele wyznaczane przez program mogą być niezgodne z potrzebami uczniów i nie wyzwalają w nich dostatecznej motywacji do angażowania się $\mathrm{w}$ wyznaczone zadania; teoria uczenia się przyjęta $\mathrm{w}$ materiałach kursowych lub rekomendowana przez specjalistów może być sprzeczna z własnym doświadczeniem nauczyciela i jego osobistą teorią; może wystąpić też wspomniany już konflikt między pojmowaniem ról społecznych. Autor proponuje też, aby spojrzeć na lekcję jako doświadczenie rozwoju nauczyciela-badacza, dzięki któremu budowana przez niego teoria uczenia się i nauczania podlegać będzie weryfikacji. Refleksyjne nauczanie, wspierane przez badanie $\mathrm{w}$ działaniu (ang. action research), jest formą doskonalenia zawodowego promowaną przez współczesne podejścia do dydaktyki językowej (np. Gabryś-Barker ${ }^{44}$ ).

Nauczyciele, jak również uczniowie, mają swoje własne teorie uczenia się i nauczania, które wszelako nie zawsze są wyartykułowane, co nie znaczy, że w działalności praktycznej nie są przestrzegane. Na przykład Łastowska ${ }^{45}$ badała stosunek nauczycieli i uczniów do pracy w grupie. Nauczyciele, którzy oceniali pracę $\mathrm{w}$ grupie jako formę mniej korzystną od nauczania frontalnego lub pracy indywidualnej, nie stosowali jej w swojej praktyce lub stosowali ją rzadko, byli też tymi, którzy nie lubili zadań opartych na pracy w grupie, gdy sami byli uczniami. Ich uczniowie natomiast mieli pozytywny stosunek do tej formy aktywności, nie widząc zagrożeń, jakie sygnalizowali ich nauczyciele (brak dyscypliny, brak zaangażowania niektórych uczniów). Gdyby jednak, mimo obaw, nauczyciele zdecydowali się wprowadzić tę formę interakcji, dostrzegliby nie tylko problemy, ale też zalety. Sformułowanie problemu wymusza poszukiwanie rozwiązań, unik jest tylko jednym z nich, a na dodatek nie sprzyja rozwo-

${ }^{43}$ N.S. P r a b h u, The dynamics..., op. cit., s. 237.

${ }^{44}$ Action Research in Teacher Development: An overview of research methodology, D. Gabryś-Barker (red.), Katowice 2011.

45 A. Ł a s t o w s k a, Group work..., op. cit. 
jowi jednostki. Utrzymanie pożądanych zachowań uczniów jest przecież celem wychowawczym, do którego powinno się dążyć, a więc jest celem rozwojowym.

Woźniewicz ${ }^{46}$ podkreśla znaczenie autorefleksji nauczyciela nad własną praktyką dydaktyczną jako istotnego czynnika w doskonaleniu zawodowym, czyli w procesie stawania się coraz lepszym i bardziej efektywnym pedagogiem. Zdolność do refleksji nad własną działalnością nazywa „umiejętnościami gnostycznymi", które są wypracowywane w działaniu, w procesie prowadzenia lekcji, i których nie można się nauczyć wyłącznie na kursach przygotowujących do wykonywania zawodu.

Obserwowane lekcje prowadzone przez nauczycieli-praktykantów wyraźnie wskazują na istotną rolę praktyk szkolno-pedagogicznych w procesie stawania się nauczycielem. Dają one możliwość zweryfikowania w praktyce wszystkich, wielorakich aspektów prowadzenia lekcji oraz funkcjonowania na wielu różnych płaszczyznach. Nauczyciele-praktykanci mają szansę wykształcić nie tylko techniczne lub czysto metodyczne sprawności i umiejętności, lecz również popracować nad społecznymi i psychologicznymi aspektami pracy nauczyciela. Niewątpliwie również, poprzez kontakty ze swoimi mentorami, przekonają się, że profesjonalny rozwój nauczyciela nigdy się nie kończy oraz że każda lekcja to wydarzenie jedyne $\mathrm{w}$ swoim rodzaju, o wyjątkowym charakterze wynikającym z konkretnej sytuacji dydaktycznej.

\section{Podsumowanie}

Lekcja języka obcego nie może być postrzegana jedynie jako 45 minut, w czasie których nauczyciel ma przekazać uczniom jak największą ilość informacji i wiedzy, choć prawdopodobnie takie przekonanie miało wielu z obserwowanych nauczycieli-praktykantów. Poza przekazywaniem pewnej wiedzy i rozwijaniem sprawności uczniów, przed nauczycielem stoi wiele innych zadań, które musi wypełnić, aby lekcja spełniała swoje różnorodne funkcje, bowiem lekcja to również czas, w którym powstają i cementują się relacje pomiędzy uczniami, w którym uczą się oni, jak się zachować w pewnej grupie społecznej, w którym często kształtują się ich postawy i przekonania, w którym nauczyciel czynnie doskonali swój warsztat dydaktyczny i umiejętności wychowawcze. Aby sprostać wyzwaniom, jakie stawia przed nauczycielem prowadzenie dobrych, wartościowych lekcji, potrzebne jest na pewno solidne przygotowanie do wykonywania zawodu, jak również pewna wrażliwość i wyczucie sytuacji oraz gotowość do spojrzenia na lekcję jako jednostkę o złożonym, wielowymiarowym charakterze. Tego wyczucia i gotowości do oceny swojej roli z szerszej perspekty-

${ }^{46}$ W. W o ź n i e w i c z, Kierowanie procesem..., op. cit., s. 269. 
wy nauczyciele nabywają wraz z doświadczeniem pedagogicznym, choć potrzebny jest do tego również wysoki poziom autorefleksji i otwarcia się na potrzeby ucznia. Tylko wtedy lekcja językowa stanie się wydarzeniem dającym uczniom możliwość pełnego rozwoju oraz źródłem satysfakcji zarówno dla uczniów, jak i dla nauczyciela. 
